\title{
NLOAD: AN INTERACTIVE, WEB-BASED MODELING TOOL FOR NITROGEN MANAGEMENT IN ESTUARIES
}

\author{
Jennifer L. Bowen, ${ }^{1}$ Joy M. Ramstack, ${ }^{2}$ S. Mazzilli, ${ }^{3}$ and Ivan Valiela ${ }^{1,4}$ \\ Boston University Marine Program, Marine Biological Laboratory, Woods Hole, Massachusetts 02543 USA
}

\begin{abstract}
Eutrophication of estuaries is an increasing global concern that requires development of new tools to identify causes, quantify conditions, and propose management options that address this environmental problem. Since eutrophication is often associated with increased inputs of land-derived nitrogen to estuaries, we developed NLOAD, a user-friendly, web-based tool that brings together six different published models that predict nitrogen loading to estuaries and two models that estimate nitrogen concentrations in coastal waters. Here we describe each of the models, demonstrate how NLOAD is designed to function, and then use the models in NLOAD to predict nitrogen loads to Barnegat Bay, New Jersey (USA). The four models that we used to estimate nitrogen loads to Barnegat Bay, when adjusted, all had similar results that matched well with measured values and indicated that Barnegat Bay receives roughly $26 \mathrm{~kg} \mathrm{~N} \cdot \mathrm{ha}^{-1} \cdot \mathrm{yr}^{-1}$. Atmospheric deposition was the dominant source of nitrogen to Barnegat Bay, followed by fertilizer nitrogen. Wastewater in Barnegat Bay is diverted to an offshore outfall and contributes no nitrogen to the system. The NLOAD tool has an additional feature that allows managers to assess the effectiveness of a variety of management options to reduce nitrogen loads. We demonstrate this feature of NLOAD through simulations in which fertilizer inputs to the Barnegat Bay watershed are reduced. Even modest cutbacks in the use of fertilizers on agricultural fields and lawns can be shown to reduce the amount of $\mathrm{N}$ entering Barnegat Bay.
\end{abstract}

Key words: Barnegat Bay; coastal planning; eutrophication; management tool; nitrogen loading; nitrogen mitigation; resource managers; watershed-estuary coupling.

\section{INTRODUCTION}

Eutrophication of coastal waters is a principal worldwide agent of change (GESAMP 1990, Goldberg 1995, Bricker et al. 1999) that is closely associated with increases in the amount of new nitrogen $(\mathrm{N})$ entering near-shore waterways. The increase in $\mathrm{N}$ loads and concentrations is largely driven by changes in land use and energy consumption associated with burgeoning populations on coastal watersheds (Howarth et al. 1996). The impact of eutrophication in estuaries is far reaching and includes increases in algal production, reduction in seagrass habitats, increases in the frequency of hypoxia, decreases in the density of benthic invertebrates, reductions in scallop harvests, and many other alterations (Valiela et al. 1992, 1997b, 2000b).

Manuscript received 24 May 2005; revised 8 December 2006; accepted 6 March 2006. Corresponding Editor: A. Townsend. For reprints of this Special Issue, see footnote 1, p. S1.

${ }^{1}$ Present address: The Ecosystems Center, Marine Biological Laboratory, Woods Hole, Massachusetts 02543 USA.

${ }^{2}$ Present address: St. Croix Watershed Research Station, Science Museum of Minnesota, Marine on St. Croix, Minnesota 55047 USA.

${ }^{3}$ Present address: Environment and Natural Resources Service, Food and Agriculture Organization of the United Nations, Rome, Italy.

${ }^{4}$ Corresponding author. E-mail: ivaliela@mbl.edu
To effectively understand and manage the increasing enrichment of coastal waters, adequate methods are required to quantify the sources of nitrogen that are inducing eutrophication. There are many models available that estimate land-derived nitrogen loads (Cole et al. 1993, Johnes 1996, Valiela et al. 1997a, Caraco and Cole 1999, Valiela et al. 2004, among others). Each model offers different levels of complexity, data demands, ease of use, and scale of application. The variety of nitrogen loading models that are available, and the diversity of structure and content of these models, makes it a demanding chore for a researcher or manager to select the appropriate model to answer the management question at hand. To facilitate this, and many other needs of scientists and managers interested in understanding the role that land-derived nitrogen plays in the eutrophication of their estuaries, we developed NLOAD (see Appendices A and B).

We present NLOAD as a web-based tool that makes a suite of models more readily available for use by stakeholders, managers, decision makers, and researchers interested in estimating or managing $\mathrm{N}$ loads from watersheds to specific estuaries. Stakeholders can use NLOAD to apply a variety of recent models to their specific estuarine system. Users of NLOAD are given descriptions of each of the models and are guided through a series of questions to help them select the model that is most appropriate for the data they have 
available. Included with NLOAD are two models, nitrogen loading model (NLM; Valiela et al. 1997a, 2000a) and estuarine loading model (ELM; Valiela et al. 2004), that we developed and verified, as well as several additional models published in the literature (Gaines 1986, Cole et al. 1993, Johnes 1996, Kellogg et al. 1996, Caraco and Cole 1999, Costa et al. 1999, Dettmann 2001). We describe the models that are included in NLOAD and provide a brief synopsis of how NLOAD works and the range of management questions that it can address. In addition, we provide an example of the use of NLOAD to assess $\mathrm{N}$ loads, sources, and management options to Barnegat Bay, New Jersey, USA, a shallow estuary where empirical estimates of $\mathrm{N}$ loads have been measured (Hunchak-Kariouk and Nicholson 2001, Kennish 2001).

\section{Models included in NLOAD}

There are many models available to assess $\mathrm{N}$ loads and concentrations. We selected a few for inclusion in NLOAD based on ease of application, feasible data demands, and inclusion of features that allow assessment of management options. Some of the models we selected were designed to deal with different forms of nitrogen, some addressed loads to the estuary, while others estimated concentrations in the estuary. Because of their diversity of formulation, the models in NLOAD provide users with the opportunity to ask questions at different levels of model complexity as well as at different spatial scales. The range of complexity in models also allows users to select a model that best fits with the data that may be available for the estuary in question.

The models differ substantially in number of required inputs, process terms, and additional components. The simplest model in NLOAD allows the user to calculate nitrogen load based only on the number of houses in the watershed, while the more complex models require additional information on land use, atmospheric $\mathrm{N}$ inputs, and fertilizer use. The models also differ in that some use proxies for major inputs (for example the number of people in cities, and consumption of fertilizers), while other models have more comprehensive formulations specifying processes (denitrification, nitrogen fixation, regeneration, etc.) in specific component environments (soils, vadose zone, aquifers, streams, wetlands, seagrass meadows, bare sediments, and so on).

It should be noted that these models do have associated uncertainties that are not taken into consideration in NLOAD. Two models in NLOAD, NLM and ELM, do have error calculations reported for them (12\% and $10 \%$, respectively, based on the propagated standard error of the means of default values used to construct the models). Error terms for the rest of the models included in NLOAD were either not reported, or were extremely low as a result of extensive calibration against measured data from the sites where the models were designed.
Many of the NLOAD models, in addition to having no reported error estimates, were also never systematically verified against measured nitrogen loads to ascertain the accuracy of the model output. To us this seems like a minimum requirement if the model is to be used to evaluate watershed management scenarios. Thus, in previous work (Valiela et al. 2002) we applied each of the NLOAD models to a series of estuaries on Cape Cod for which we have extensive measured data. Our goal was to evaluate the accuracy and responsiveness (among other features) of each of the models using statistical indicators. The majority of the models that we compared, and all of the models that are included in NLOAD, were responsive to changes in watersheds when tested against a series of estuaries that span a broad range of watershed land use types, and hence nitrogen loads. Most of the models, however, lacked accuracy, in that they systematically over-estimated nitrogen loads compared to measured values (Valiela et al. 2002). The differences in the various model outputs stem from the different data requirements and the diversity of model formulations among the group of models that are included in NLOAD.

Since the models included in NLOAD were appropriately responsive to changes in nitrogen loads, we were able to apply a correction factor, derived from the regression equation of the modeled vs. measured data (Valiela et al. 2002) that greatly improved model accuracy for those models that over-estimated nitrogen load. In fact, when the adjustment factors were used for each of the models included in NLOAD, there were no significant differences between the modeled nitrogen loads and measured nitrogen loads when applied to the suite of Cape Cod estuaries for which we had measured data. The inclusion of these adjustment factors greatly increases the utility of the NLOAD tool, as it allows reasonably accurate estimates of nitrogen loads to be made even when minimal input data are available. These adjustment factors do not, however, provide any information on what terms in the original model formulation need to be examined more closely to have accurate model results.

At the present time, NLOAD includes eight models; more models can easily be added as they become available. Six of the models in NLOAD are wholewatershed, landscape models that estimate the nitrogen loading from the watershed to the receiving estuary, but do not take into account additional losses of nitrogen that may occur through processing during transport in streams or through fringing wetlands. All of these models deal with nonpoint sources of $\mathrm{N}$, but an estimate of $\mathrm{N}$ loading from a point source can be added to the total $\mathrm{N}$ load predicted by any of these models if the point source is disposed of directly into the adjoining estuary. Four of the six landscape models (nitrogen loading model [NLM; Valiela et al. 1997a], P. Johnes model [PJM; Johnes 1996], Buzzards Bay Project model [BBP; Costa et al. 1999], and the on-site and fertilizer 
model [OSF; Gaines 1986]) predict loads of total dissolved nitrogen (including organic and inorganic nitrogen) to the estuary, while two of these models (Caraco and Cole model [CC; Caraco and Cole 1999]), and the method for assessment, nutrient-loading, and geographic evaluation of nonpoint pollution model [MANAGE; Kellogg et al. 1996]) predict nitrate load.

Two additional models in NLOAD predict the concentration of $\mathrm{N}$ in receiving water bodies. The estuarine loading model (ELM; Valiela et al. 2004) predicts the total concentration of dissolved inorganic nitrogen (DIN) in estuaries, and the Dettmann model (DVM; Dettmann 2001) predicts the total nitrogen concentration in the water. We provide brief descriptions of the model formulations for each of the models included in NLOAD.

The nitrogen loading model (Valiela et al. 1997a, $2000 a$ ) predicts total dissolved nitrogen loads to estuaries in watersheds where groundwater flow dominates. To achieve this, NLM considers inputs from three major sources of nitrogen: wastewater (via septic systems, using values for contribution of $\mathrm{N}$ per house; direct point sources, such as outfalls from sewage treatment plants, are added separately), fertilizer (from use on turf and agriculture), and atmospheric deposition on the watershed. The NLM accounts for losses of $\mathrm{N}$ as it passes through various land covers (residential area, turf, natural vegetation, etc.), as well as losses during travel through the soils, vadose zone, and aquifer. The NLM is appropriate for use in systems where extensive land-use information is available. This model is advantageous because of its relatively high accuracy (Valiela et al. 2002) and because it partitions the nitrogen load into component sources.

The NLM has an added feature that makes it somewhat more spatially explicit than the other models included in NLOAD. All of the models can be used to calculate nitrogen loads for subwatersheds that are not hydrologically connected to one another, but the NLM also has the capacity to predict nitrogen loads to nested watersheds. On the NLM input page there is a feature incorporated into the "area of freshwater ponds" input term that allows the user to calculate $\mathrm{N}$ loads for watersheds up-gradient of freshwater ponds that intercept groundwater. This feature calculates the losses of $\mathrm{N}$ in the up-gradient watershed and in the pond itself, and then treats the remaining $\mathrm{N}$ as an additional source to down-gradient estuaries. This formulation allows NLM to be used in watersheds with some hydrological complexity. This model does, however, require detailed land cover information and knowledge of associated land use in both up-gradient and down-gradient watersheds, information that may not be available for all systems.

The P. Johnes model (Johnes 1996) predicts export of total $\mathrm{N}$ from watersheds that are dominated by agricultural to suburban land uses. The model incorporates inputs on the amount of $\mathrm{N}$ from human and livestock wastes, fertilizer use, $\mathrm{N}$ fixation in different land cover types, and atmospheric deposition. The PJM estimates losses of $\mathrm{N}$ using a loss coefficient approach, in which loss terms were calibrated against measured data. This input-and-loss-coefficient approach is similar to that of Omernik (1976), Beaulac and Reckow (1982), and Soranno et al. (1996). This approach results in models that are highly accurate for the system in which they are validated, but may limit their transferability (Valiela et al. 2002). We did, however, compare the output of the PJM against measured values for a suite of Cape Cod estuaries, and the model performed with reasonable precision in systems for which it was not calibrated. A small adjustment factor can be applied to improve the accuracy of the PJM in other systems (Valiela et al. 2002).

The PJM is unique in that it includes terms for nitrogen fixation in both agricultural and naturally vegetated land parcels, so it is a good choice for ecosystems in which those are thought to be the dominant sources of nitrogen. As with the NLM, the PJM also requires detailed information about land use and is only appropriate for watersheds in which this information is available.

The Buzzards Bay Project model (Costa et al. 1999) was initially developed to predict total nitrogen loads to Buzzards Bay, Massachusetts. The BBP model calculates total dissolved $\mathrm{N}$ based on assessments of the amount of $\mathrm{N}$ generated per area of land use type. For example, the model considers that $15.3 \mathrm{~kg} \mathrm{~N} / \mathrm{ha}$ are produced from driveways, and it multiplies this factor by the entire area of driveways in the watershed. It then sums the nitrogen contributed from each of the land use types to predict a total nitrogen load from the watershed. It additionally incorporates the contribution of wastewater nitrogen based on the number of people living in the watershed. The BBP model is designed to interface seamlessly with GIS land use outputs and works well for systems in which those data are available. Since the BBP model uses one expression to describe the load from different land uses, it is impossible to partition $\mathrm{N}$ derived from fertilizer with $\mathrm{N}$ derived from atmospheric sources, and is thus less helpful in analysis of diverse mitigation strategies.

The on-site and fertilizer model (Gaines 1986) was designed to provide rough estimates of nitrogen loads in groundwater-based systems in which little preexisting data are available. The only input term for this model is the number of houses in the watershed. The model then assumes that each house contributes $6.8 \mathrm{~kg} \mathrm{~N} / \mathrm{yr}$ in septic $\mathrm{N}$, and $4.8 \mathrm{~kg} \mathrm{~N} / \mathrm{yr}$ in fertilizer $\mathrm{N}$. The OSF model does not include a term for atmospheric $\mathrm{N}$ deposition. The OSF model is best applied to watersheds in which septic systems are the primary means of wastewater disposal, and agriculture is not a dominant feature of the landscape.

In contrast to the models described above, the model of Caraco and Cole (Caraco and Cole 1999) predicts 
land-derived nitrate load to the receiving estuary. The $\mathrm{CC}$ model calculates nitrate load as the sum of wastewater (based on urban population), fertilizer (based on area in agriculture), and atmospheric deposition (based on local data). The $\mathrm{CC}$ model assumes that $60 \%$ of the wastewater $\mathrm{N}$ generated by urban populations is removed via waste treatment, and that the portion of fertilizer and atmospheric $\mathrm{N}$ removed is a function of water flux. This model was initially applied to predict nitrate export from large riverine systems. It does not provide spatially explicit information on nitrogen sources, but if water flux information is available the model does predict loads to large systems with very few data requirements.

The method for assessment, nutrient-loading, and geographic evaluation model (MANAGE; Kellogg et al. 1996) is one of the more complicated models included in NLOAD. It has two components, a surface-water model that predicts total nitrogen loads, and a groundwater model that predicts $\mathrm{NO}_{3}$ loads. The surface model uses export coefficients to predict the total $\mathrm{N}$ derived from 21 different land covers in the watershed. It adds to this a calculation for the $\mathrm{NO}_{3}$ that is delivered via groundwater from functioning septic systems, agricultural and lawn fertilizers, pets, and atmospheric deposition. The model includes terms for losses of $\mathrm{N}$ in groundwater that vary by source. The MANAGE is also designed so that the land use requirements can be easily derived from GIS data where available. It is a good model to use in systems where both surface and groundwater flows are common, and where a lot of preexisting information about the watershed is available.

The Cole, Peierls, Caraco, and Pace model (CPCP; Cole et al. 1993) predicts the nitrate concentration in receiving river water based on the human population in the watershed. The only input necessary is the number of people living within the watershed boundary. The model uses a log-log regression equation from population data of major watersheds throughout the world to predict $\mathrm{NO}_{3}$ concentration. As with the OSF model, CPCP is a good model to use to get a first-cut estimate of $\mathrm{NO}_{3}$ concentrations in systems where little watershed information is available. This model has an additional advantage - since it was created from a comparison of a broad range of systems, it can be used, in consultation with the original manuscript, to compare individual results with results from other systems around the globe.

The estuarine loading model (ELM; Valiela et al. 2004) estimates the annual average concentration of DIN in receiving waters. As a first step, the model requires an input of land-derived $\mathrm{N}$ load (from the NLM or one of the other loading models). Additional data requirements include areas of salt marsh, bare sediment, and seagrasses, as well as estimates of flushing time of the estuary. The model accounts for inputs (from direct atmospheric deposition onto the surface of the estuary and from $\mathrm{N}_{2}$ fixation and benthic regeneration) within each of these habitats, and losses (from denitrification, burial, and export), to arrive at an annually averaged DIN concentration. This model is unique in that it can provide managers with an assessment of the amount of $\mathrm{N}$ that is directly available for uptake by primary producers, and is thus a useful tool for linking landderived change with eutrophication of coastal waters.

The ELM also takes into account the nitrogen losses that occur as $\mathrm{N}$ moves from watersheds to estuaries through surface water flow. The ELM includes input terms for the amount of $\mathrm{N}$ entering freshwater reaches of streams, and the residence time of water in those streams, to account for losses of $\mathrm{N}$ through hyporheic exchange. This is thus the best model for predicting DIN concentrations in receiving waters, but it does have significant data requirements, including the area of major benthic habitats, and estimates of flushing time or basin bathymetry that may not be available for all systems.

The Dettmann model (DVM; Dettmann 2001) is similar to the ELM in that it uses flushing times and a previously determined estimate of land-derived nitrogen load to predict the mean annual total nitrogen concentration in the receiving estuary. This model uses a Vollenweider (1976) approach, in which it calculates the concentration of $\mathrm{N}$ based on land- and sea-derived $\mathrm{N}$ sources and the volume of the receiving water body. It then applies a loss coefficient of $0.01 \mathrm{~d}^{-1}$ for estuaries (i.e., $1 \%$ daily loss of total nitrogen in the estuary), a rate derived from a comparison of 11 estuaries in North America and Europe. The DVM is advantageous because it does not require information on each of the different benthic habitat types, but, it may be less ecologically relevant than the ELM, because it considers only total $\mathrm{N}$, rather than separating into labile and refractory components.

\section{Description of NLOAD}

The NLOAD tool is organized as a series of four programming modules: inputs, models, outputs, and an administration module (Fig. 1). The input module is the web-based interface that guides users through the different tasks that are available. It provides links to pertinent background information, and is where users select the models that they choose to run. The second module consists of the loading models, the concentration models, and a mechanism by which these models can be used to assess the effectiveness of management options (Fig. 1). In this module users can examine the details of the models that they are using and can make adjustments to the model terms to reflect locally relevant data. The models then feed into an output module (Fig. 1) that allows the user to save the model results, along with the input data, in a variety of different formats. The entire program is maintained by an administration module (Fig. 1), which is invisible to users, but necessary to allow administrative access to the web site. We use this module to keep track of user data files, delete users, and update existing models as modifications are made available. This module also allows us to easily add new models to the 


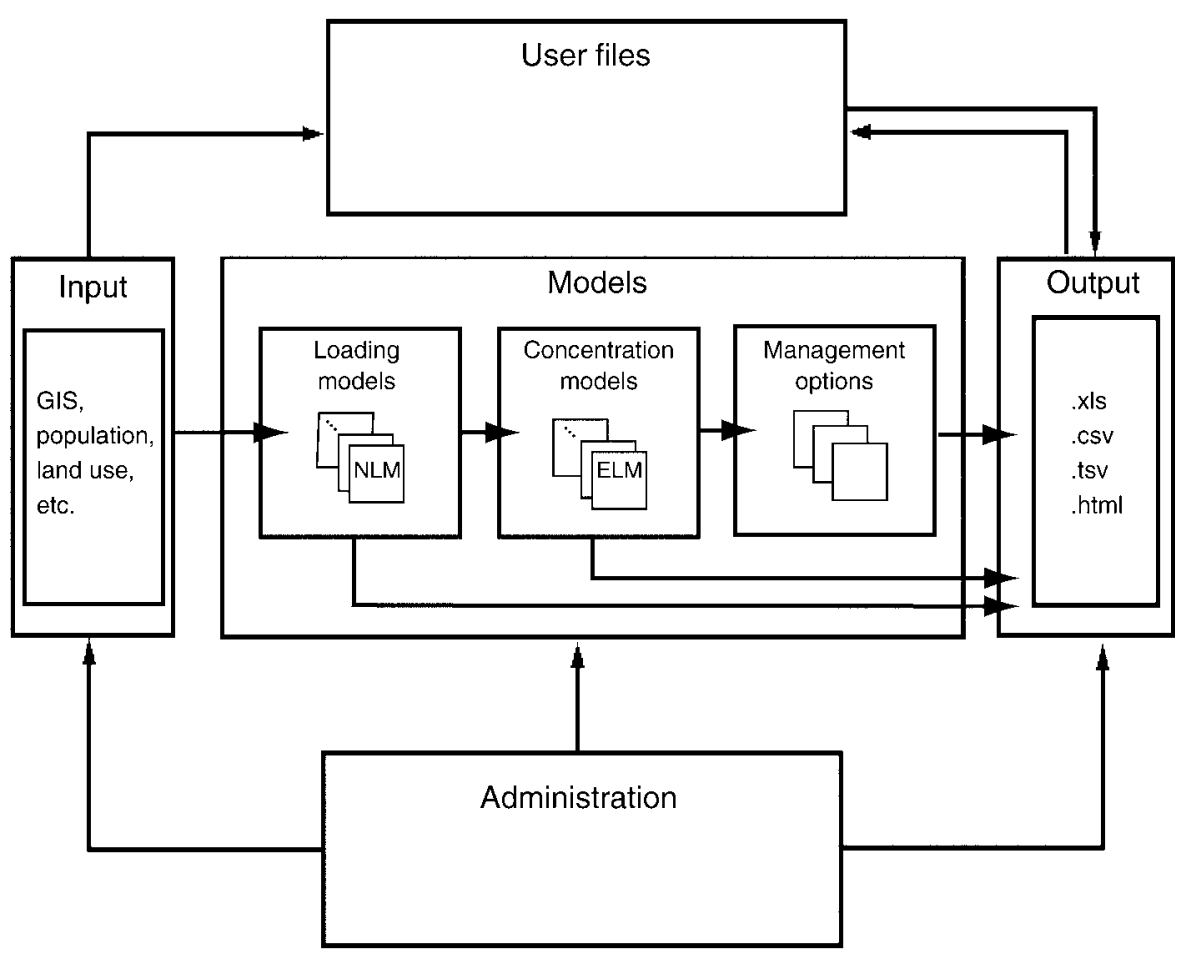

FIG. 1. Schematic diagram of the overall NLOAD design.

web site. We briefly describe some of the pages users will encounter as they explore NLOAD and its applications.

NLOAD frontispiece.-NLOAD has a user-friendly web interface that introduces the tool and allows users to $\log$ in (available online). ${ }^{5}$ When users establish an account, they are able to save their input data and model results in a password-protected personal account for future access. This page also provides a guide for navigating the site that can be saved, as well as printed, for future reference. Once users $\log$ in, they are presented with further details about NLOAD, with links to pages that contain definitions of terms and background information necessary to understand the modeling procedure. From these introductory and background pages users are directed to the main menu.

NLOAD main menu.-The main menu of NLOAD provides users with several options, including additional links to the background information and navigation guide. From the main menu users can also access previously saved data files. This page has a table that compares the various models, provides links to brief descriptions of the models, and lists the published references for the original modeling work. Additionally, there is a link that acknowledges the contributors to the creation of NLOAD, and to various sources of funding. Finally, from the main menu users can move forward by clicking on the "carry out tasks" link.

NLOAD task list page.-These pages guide the user

${ }^{5}\langle$ http://nload.mbl.edu $\rangle$ through a selection of various nitrogen loading tasks that can be addressed by NLOAD. These tasks are presented as a series of questions, and based on users' responses to questions posed, a subset of the NLOAD models are presented that are relevant to their particular goals. This makes the selection of the appropriate model a less daunting procedure, allowing the user to focus on the task they would like to address. Tasks that NLOAD can address, among others, include the following: estimates of the total nitrogen load to, or nitrogen concentration (including TMDLs) in receiving waters, and estimates of the relative importance of wastewater, fertilizers, and atmospheric deposition to the total nitrogen load from a specific watershed.

The NLOAD tool then guides the user through a few additional questions that help to select the most appropriate model. This saves the user the considerable chore of pouring through the published descriptions of the various models by providing easy access to information on the model structure and on the relative transferability, complexity, accuracy, and uncertainty of the various models. Once these questions are answered, NLOAD presents the user with a list of models that can be used to deal with the specific task of interest. The models are listed in order of increasing number of required user inputs. By clicking on the name of one of the models, users are directed to the input page for that model. The user can then examine the necessary input data and further information on the selected model to determine if all necessary input information is available. If some information is lacking, the user is prompted to 


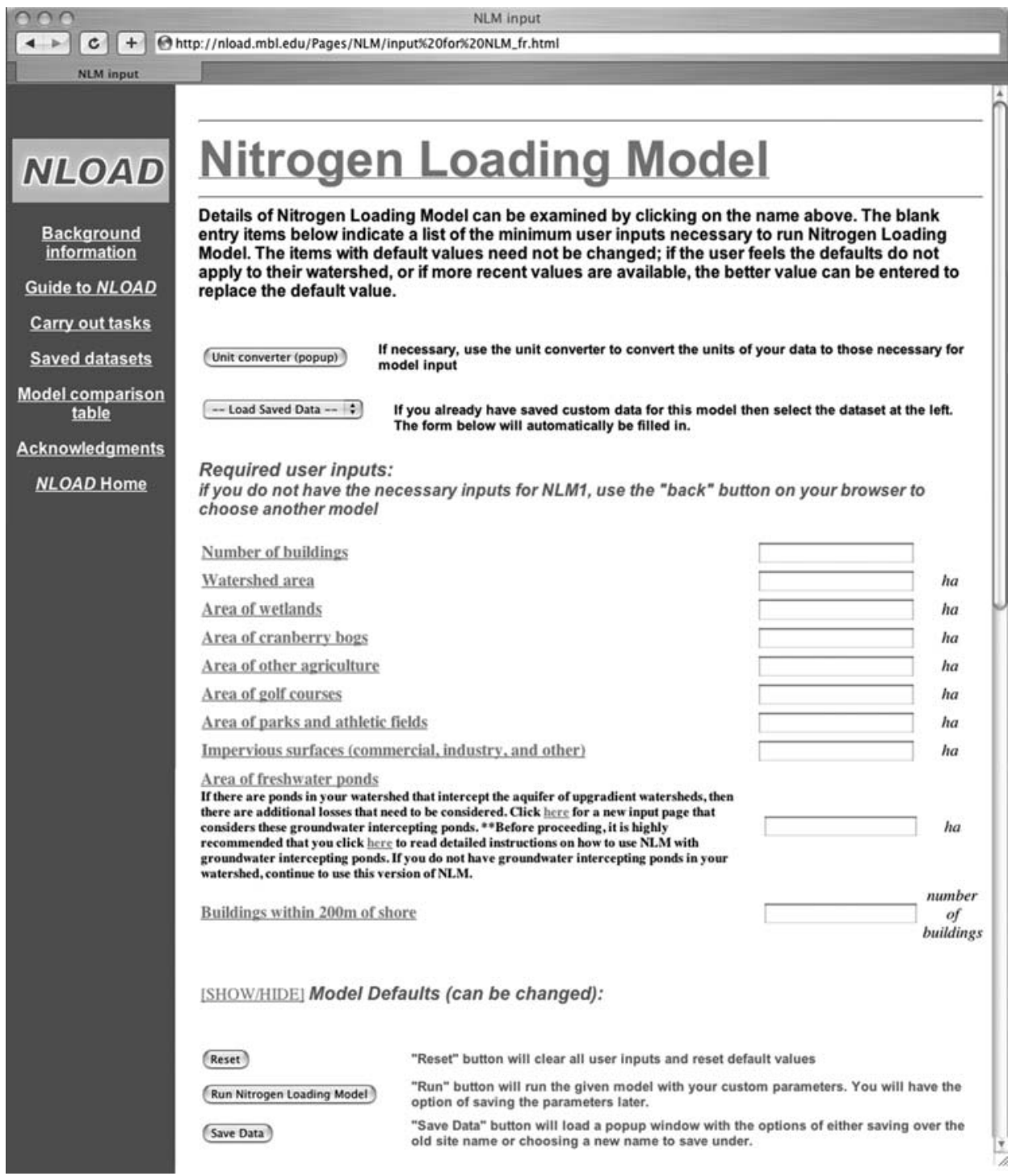

FIG. 2. Screen capture of the page from the NLOAD web site that allows users to enter data into the nitrogen loading model (NLM).

return to the original list and select a different model. After users select the appropriate model, they are directed to the input page for that model.

NLOAD input page.-Here we show the input page for one of the models, NLM, as an example (Fig. 2). There are many features in the input pages for this and other models that need to be noted. First, the user can click on the model name to read a brief synopsis of the model algorithm and find a reference to the original manuscript if more information is desired. A drop-down menu stores inputs that were previously saved so that users can avoid reentering data for multiple model runs. Selecting one of these saved data sets automatically fills in the input with the stored data. Below the drop-down menu is a list of user inputs (Fig. 2). An added feature of the input page is the pop-up unit converter (Fig. 2), allowing the user to convert the units of their data to those necessary for model input. Some models provide "default" input and process values in absence of local data. The function at the bottom of the page to "show/hide model defaults" allows users to examine default values to ascertain if they are appropriate for application. If not, users can change the defaults to values that are more locally relevant. Once the user is satisfied with the input and default data, clicking the run model tab at the bottom of the page cues the model to process the data, and report the result in an output page.

NLOAD output page.-The output pages are similar in structure to the input pages. In addition to listing the model results, the output page offers the option to show or hide the previously entered model inputs, and to show or hide the intermediate calculations needed to produce the model results. The listing of model results will vary depending on the chosen model. At the bottom of the 
TABLE 1. Data derived from GIS for land use and population for several subwatersheds and the entire subwatershed of Barnegat Bay, New Jersey, USA.

\begin{tabular}{|c|c|c|c|c|c|c|c|}
\hline \multirow[b]{2}{*}{ Subwatershed } & \multirow[b]{2}{*}{$\begin{array}{l}\text { No. } \\
\text { people }\end{array}$} & \multicolumn{6}{|c|}{ Area (ha) } \\
\hline & & Watershed & $\begin{array}{l}\text { Freshwater } \\
\text { wetlands }\end{array}$ & Salt marsh & Agriculture & Lakes & $\begin{array}{c}\text { Impervious } \\
\text { surfaces }\end{array}$ \\
\hline Metedeconk River & 159528 & 22356 & 5666 & 145 & 864 & 952 & 3220 \\
\hline Toms River-Kettle Creek & 226047 & 56431 & 10882 & 567 & 1275 & 1108 & 5615 \\
\hline Cedar Creek-Forked River & 38848 & 24263 & 4690 & 792 & 109 & 505 & 984 \\
\hline Oyster Creek & 16898 & 9017 & 2212 & 1826 & 15 & 212 & 370 \\
\hline Mill Creek & 28867 & 18464 & 3323 & 2394 & 73 & 262 & 729 \\
\hline Tuckerton Creek & 16142 & 8626 & 614 & 2096 & 9 & 218 & 349 \\
\hline Total basin & 486330 & 139157 & 27388 & 7821 & 2346 & 3256 & 11268 \\
\hline
\end{tabular}

Notes: Area of land in natural vegetation is calculated as the difference between the total watershed area and the sum of all other land uses. Data are courtesy of Scott Haag from the Grant F. Walton Center for Remote Sensing and Spatial Analysis at Rutgers University (personal communication).

output page, users can save model results for subsequent use in NLOAD, as well as export the data in a number of formats to be used in other programs. Formats include Microsoft Excel, and comma- or tab-delimited files. Users can continue by clicking on the "proceed to management options" tab.

NLOAD management options.-There are several management options available for analysis in NLOAD. These management options are available for use only with two models, NLM and ELM, as the other models included in NLOAD do not have sufficient detail to assess the effectiveness of many of the management options considered. The management options discussed range from changes that can be made in the watershed, such as reducing wastewater and fertilizer inputs, to changes that can be made within the estuary, such as harvesting macroalgae and dredging estuary channels. For each of the topics discussed, the user is given instructions as to which input or default value needs to be changed on the model input pages to see how the chosen management option would affect their estuary.

\section{An example application of NLOAD: Barnegat Bay, New Jersey}

Barnegat Bay is a shallow, lagoon-type estuary that has been classified as highly eutrophic (Kennish et al. 2007). This estuarine system is particularly vulnerable to a reduction in water quality because the system has a highly urbanized watershed, relatively low inputs of freshwater, and long water residence times (Kennish et al. 2007). The combined effect of these three stressors has become apparent in the ecology of Barnegat Bay. There have been reports of extensive phytoplankton and macroalgal blooms (Olsen and Mahoney 2001, Kennish et al. 2007). The area of seagrasses decreased by $>60 \%$ from 1970 to 2000 (Bologna et al. 2001), and there have been cascading effects on the stocks of the hard shell clam Mercenaria mercenaria (NJDEP 2002). These shifts in the ecology of Barnegat Bay indicate that the estuary is experiencing some of the symptoms of eutrophication.

Eutrophication of coastal waters has been linked to increases in land-derived nitrogen loads that stem from urbanization of coastal watersheds (Lee and Olsen 1985, Nixon et al. 1986, Valiela et al. 1992). An increasing number of humans results in increased $\mathrm{N}$ from three major sources: atmospheric deposition on the watershed and on the surface of the estuary, fertilizer application, and human-derived wastewater. Barnegat Bay is atypical of many estuarine systems in the world in that it receives no nitrogen contribution from human-derived wastewater, so the only significant sources of $\mathrm{N}$ to Barnegat Bay are from atmospheric deposition and from fertilizer use. In the Barnegat Bay watershed, human wastewater is instead collected and processed in sewage treatment plants, and the effluent is disposed of through offshore outfalls. In a comparison of 20 estuaries throughout the northeastern United States, wastewater accounted for $2-82 \%$ of the total nitrogen entering receiving waters (Cole et al. 2004), and wastewater has been linked to fundamental changes in the ecology of estuaries (McClelland et al. 1997, McClelland and Valiela 1998, Cole et al. 2004).

Despite the diversion of wastewater from Barnegat Bay, there have still been fundamental changes to the ecology of the bay. These changes in Barnegat Bay have prompted managers in the watershed to seek new methods for quantifying and managing $\mathrm{N}$ loads entering the bay, and thus we chose this system as a model system to demonstrate the utility of NLOAD. We use Barnegat Bay as a case study to show a few key features of NLOAD. (Note that NLOAD has many more features than can be reasonably illustrated here; we direct the reader to Appendices A and B and to the NLOAD web site to fully explore all of the features of the tool [see footnote 5].)

\section{Methods used in the application of NLOAD to Barnegat Bay}

As a first step for the application of NLOAD, we acquired GIS-compiled land use information from Scott Haag at the Grant F. Walton Center for Remote Sensing and Spatial Analysis at Rutgers University (Table 1). We combined the data into six major subwatersheds (Fig. 3) that drain into Barnegat Bay, 


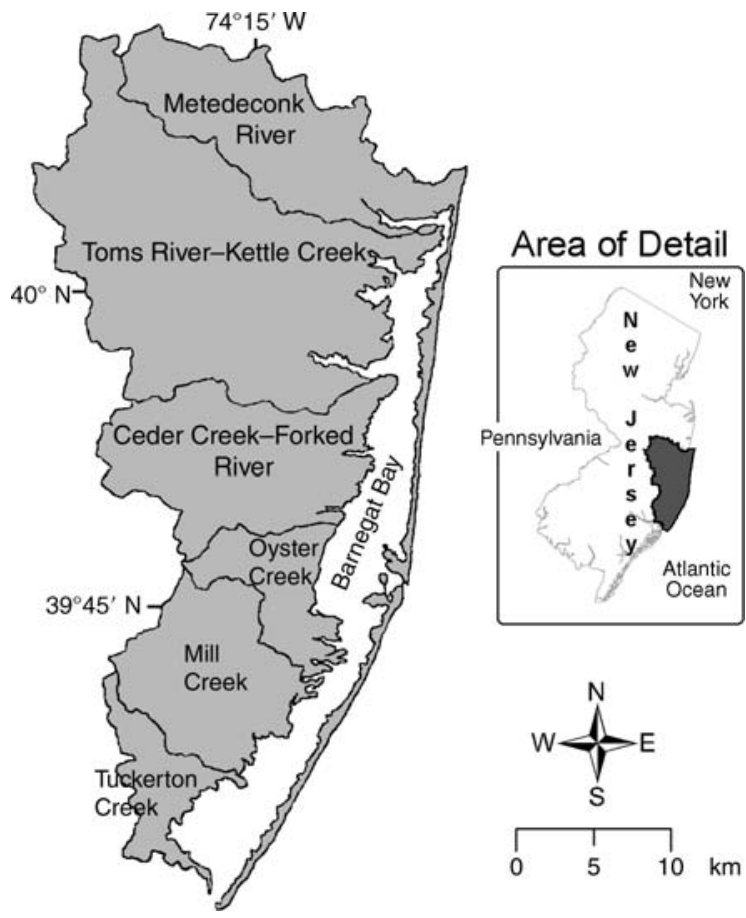

FIG. 3. Map of the Barnegat Bay (New Jersey, USA) watershed and the six subwatersheds that were used in this study.

and then used NLOAD to perform a number of tasks at two different spatial scales: the whole watershed scale and the subwatershed scale.

Watershed-scale.-At the whole watershed scale we first wanted to compare the relative effectiveness of the different models in NLOAD at predicting land-derived nitrogen loads to Barnegat Bay. To do this we entered the GIS-determined land use information into four of the models available in NLOAD: OSF, NLM, BBP, and PJM. Then we obtained estimates of the total nitrogen load to the bay using each of these models. Where necessary, we modified the modeled estimates with previously described adjustment factors (Valiela et al. 2002) that improve model accuracy. We then compared modeled estimates with empirical estimates of $\mathrm{N}$ loads to Barnegat Bay.

Empirical estimates of $\mathrm{N}$ loads to Barnegat Bay were derived from a combination of surface runoff discharge, groundwater discharge, and direct deposition of nitrogen to the surface of the bay (Hunchak-Kariouk and Nicholson 2001, Kennish 2001). Surface runoff from major tributaries was estimated from a network of stream gauges that covered $>850 \mathrm{~km}^{2}$ of the watershed (Hunchak-Kariouk and Nicholson 2001). Discharge from groundwater was estimated from GIS maps of those portions of the watershed that do not feed into the previously mentioned tributaries. These surface and groundwater flows were then multiplied by nitrogen concentrations from extensive groundwater and surface water monitoring stations distributed throughout the watershed (Hunchak-Kariouk and Nicholson 2001). We then added estimates of nitrogen from direct atmospheric deposition that were calculated from a network of monitoring sites throughout New Jersey and Maryland (Hunchak-Kariouk and Nicholson 2001).

We included estimates of direct atmospheric deposition to the surface of the bay as well as atmospheric deposition that falls on the watershed and is transported to the bay via surface runoff and groundwater. Both sources of deposition can be important components of nitrogen loads: direct deposition alone accounted for $31-79 \%$ of the total load to several Cape Cod, Massachusetts, estuaries (Valiela and Bowen 2002) and accounted for $25-71 \%$ of new nitrogen to large coastal regions of the North Atlantic (Paerl and Whitall 1999). To make the model estimates comparable to the empirical estimates, we added a term for direct deposition to the estimates of $\mathrm{N}$ inputs obtained from each model.

Our second goal at the whole-watershed scale was to demonstrate how NLOAD can be used to partition total nitrogen loads into the dominant sources of land-derived $\mathrm{N}$ and how this information can further guide management options. For the purposes of this exercise we went back into NLOAD and used the NLM to predict the total nitrogen load to Barnegat Bay. The NLM is able to completely partition the total load into its component parts and thus can be used to better understand the impact of management plans. From the output page of our model run, we clicked on the "proceed to management options" tab, where NLOAD offers step-by-step instructions how to adjust the specific default terms appropriate for each management scenario.

As a demonstration of how NLOAD can be used to guide management options, we examined one of the many management options available to lower $\mathrm{N}$ loads (Bowen and Valiela 2004), the reduction in fertilizer use on the Barnegat watershed. There are two possible ways to simulate reduction of fertilizer-derived nitrogen loads: decrease the dose of fertilizer, or decrease the area of land that receives fertilizers. The NLM includes terms for use of fertilizer on agricultural land, lawns, and golf courses. For example, the model assumes that agricultural fields are fertilized at a rate of $136 \mathrm{~kg} \mathrm{~N} \cdot \mathrm{ha}^{-1} \cdot \mathrm{yr}^{-1}$. We sequentially changed this default term to calculate the reduction in total nitrogen load that would occur if this dose were decreased by $90 \%, 75 \%, 50 \%, 25 \%$, and $10 \%$. To examine the effectiveness of decreasing the area of land receiving fertilizer, we used the NLM to sequentially decrease the percentage of homes that fertilize lawns from the default of $34 \%$ down to $0 \%$. The NLOAD tool could of course also be used to run simulations that reduce the area of agricultural land and golf courses that receive fertilizers.

Subwatershed-scale.--Looking at scales smaller than the entire watershed can help managers focus on management scenarios for specific regions of a watershed. In a watershed as large as Barnegat Bay, best 
TABLE 2. Comparison of estimates of land-derived, nonpoint source, nitrogen loads to Barnegat Bay obtained using four models available in NLOAD.

\begin{tabular}{|c|c|c|c|c|c|c|}
\hline \multirow[b]{2}{*}{ Model } & \multirow[b]{2}{*}{$\begin{array}{l}\text { Modeled N load } \\
\qquad\left(10^{5} \mathrm{~kg} / \mathrm{yr}\right)\end{array}$} & \multirow[b]{2}{*}{$\begin{array}{l}\text { Adjustment } \\
\text { factor }(\%)\end{array}$} & \multirow[b]{2}{*}{$\begin{array}{l}\text { Adjusted N load } \\
\quad\left(10^{5} \mathrm{~kg} / \mathrm{yr}\right)\end{array}$} & \multirow{2}{*}{$\begin{array}{l}\text { Direct atm. } \\
\text { dep. to Bay } \\
\left(10^{5} \mathrm{~kg} / \mathrm{y}\right)\end{array}$} & \multicolumn{2}{|c|}{ Nitrogen load } \\
\hline & & & & & $\begin{array}{l}\text { Total to estuary } \\
\quad\left(10^{5} \mathrm{~kg} / \mathrm{yr}\right)\end{array}$ & $\begin{array}{l}\text { Total per estuary area } \dagger \\
\left(\mathrm{kg} \mathrm{N} \cdot \mathrm{ha}^{-1} \cdot \mathrm{yr}^{-1}\right)\end{array}$ \\
\hline OSF & 9.9 & 43 & 4.3 & 3.0 & 7.3 & 25.6 \\
\hline NLM & 3.9 & $\cdots$ & 3.9 & 3.0 & 6.9 & 24.5 \\
\hline BBP & 12.6 & 44 & 5.5 & 3.0 & 8.5 & 30.1 \\
\hline PJM & 7.9 & 51 & 4.0 & 3.0 & 7.0 & 24.8 \\
\hline Empirical & & & & & 7.9 & 28.0 \\
\hline Empirical§ & & & & & 7.2 & 25.5 \\
\hline
\end{tabular}

Notes: Key to abbreviations for models: OSF, on-site and fertilizer model; NLM, nitrogen loading model; BBP, Buzzards Bay Project model; PJM, P. Johnes model. Adjustment factors are from Valiela et al. (2002).

$\dagger$ Nitrogen load per unit area of estuarine surface water, calculated as the total nitrogen load divided by the area of Barnegat Bay (28378 ha).

\$ Data source: Kennish (2001).

$\S$ Data source: Hunchak-Kariouk and Nicholson (2001).

management practices for one region of the watershed may not be best for another region. To address this issue, NLOAD provides the flexibility of examining nitrogen loads at small spatial scales. To demonstrate how NLOAD can be used at the subwatershed scale, we used land use data for six subwatersheds provided by the Grant F. Walton Center for Remote Sensing and Spatial Analysis at Rutgers University (Fig. 3). We ran the NLM in NLOAD for each of the subwatersheds, and used the model results to determine which subwatershed contributed the most nitrogen to Barnegat Bay, along with determining the dominant source of nitrogen from each of the subwatersheds. Once the dominant sources of nitrogen to the subwatersheds were determined, NLOAD was used to determine the most effective management options for reducing nitrogen loads to smaller subsections of the watershed. As an example of how NLOAD does this, we used the NLM in NLOAD to assess the effectiveness of reducing fertilizers to the Toms River-Kettle Creek subwatershed. In this scenario we sequentially adjusted the default terms to lower the amount of $\mathrm{N}$ applied to agriculture and to lawns by up to $100 \%$.

\section{Results of the application of NLOAD to Barnegat Bay}

Watershed-scale estimates of $N$ load to Barnegat Bay.-In our first simulation, we tested how the different models included in NLOAD, with their different formulations and different input requirements, compared at predicting the nitrogen load to Barnegat Bay. Using four different models, we estimated the $\mathrm{N}$ loads for Barnegat Bay (Table 2). These four models estimated that $3.9 \times 10^{5}$ to $1.26 \times 10^{5} \mathrm{~kg} \mathrm{~N} / \mathrm{yr}$ enters Barnegat Bay (Table 2, second column). We applied previously derived adjustment factors (Table 2, second column) from Valiela et al. (2002), and calculated adjusted-modeled $\mathrm{N}$ loads (Table 2, column 4). We then added the values for direct deposition (Kennish 2001) and divided by the area of Barnegat Bay to get an estimate of total $\mathrm{N}$ load per hectare of estuary surface for Barnegat Bay (Table 2).
The results of these calculations show that the modeled total $\mathrm{N}$ load to Barnegat Bay ranged over a reasonably narrow range: $24.5-30.1 \mathrm{~kg} \mathrm{~N} \cdot \mathrm{ha}^{-1} \cdot \mathrm{yr}^{-1}$ (Table 2, last column). Previously reported empirical estimates spanned $25.5-28 \mathrm{~kg} \mathrm{~N} \cdot \mathrm{ha}^{-1} \cdot \mathrm{yr}^{-1}$ (Table 2, last column). These estimates are on the low end of nitrogen loading estimates from different estuaries throughout the world that span 14-600 $\mathrm{kg} \mathrm{N} \cdot \mathrm{ha}^{-1} \cdot \mathrm{yr}^{-1}$ (Table 3).

The application of these models to Barnegat Bay provides a test of the utility of the NLOAD tool. The inputs for each of the models were derived from land use on the Barnegat Bay watershed. Although the initial model outputs fell within $3.9-12.6 \times 10^{5} \mathrm{~kg} / \mathrm{yr}$, when we applied the adjustment factors that were independently determined from comparisons between measured and modeled loads on Cape Cod, Massachusetts (Valiela et al. 2002), the model predictions to Barnegat Bay spanned a much more narrow range $\left(3.9-5.5 \times 10^{5}\right.$ $\mathrm{kg} / \mathrm{yr})$. We therefore have some confidence that, when the independently derived adjustment factors are included, all the models perform reasonably well at predicting nitrogen loads, regardless of the complexity of the model formulation.

Nitrogen loading alone, however, is not an adequate indicator of eutrophication (Nixon 1995), as this inorganic input is frequently mediated by the flushing times of the system and by top-down grazing pressure (Nixon 1995). In studies of the impacts of $\mathrm{N}$ loads on producers within estuarine ecosystems, Valiela et al. (2000b) suggested that longer water residence times enhance the dominance of phytoplankton, and can lead to high chlorophyll concentrations. Despite the fact that Barnegat Bay receives a comparably low nitrogen input, when examined in the context of organic carbon loading, Barnegat Bay seems to fall within eutrophic to hypereutrophic conditions (Table 4). Such a status seems inconsistent with the continued presence of eelgrass (Zostera marina) meadows to Barnegat Bay, since other studies indicate a dramatic decrease in the area of eelgrass when $\mathrm{N}$ loads exceed $20 \mathrm{~kg} \mathrm{~N} \cdot \mathrm{ha}^{-1} \cdot \mathrm{yr}^{-1}$ and complete eradication by the time $\mathrm{N}$ loads reach 100 
TABLE 3. Comparison of nitrogen loading rates (per hectare of water body) from a variety of international estuaries.

\begin{tabular}{lcl}
\hline \hline \multicolumn{1}{c}{ Estuary } & $\begin{array}{c}\mathrm{N} \mathrm{load} \\
\left(\mathrm{kg} \mathrm{N} \cdot \mathrm{ha}^{-1} \cdot \mathrm{yr}^{-1}\right)\end{array}$ & \multicolumn{1}{c}{ Reference } \\
\hline Sage Lot Pond, Massachusetts, USA & 14 & Valiela et al. (2000a) \\
Moreton Bay, Australia & 24 & O'Donohue et al. (2000) \\
Barnegat Bay, New Jersey, USA & $24.5-30.1$ & This study \\
Tampa Bay, Florida, USA & 28 & Bianchi et al. (1999) \\
Chincoteague Bay, Virginia, USA & 31 & Boynton et al. (1996) \\
Sarasota Bay, Florida, USA & 56 & Bianchi et al. (1999) \\
Venice Lagoon, Italy & 130 & Sfriso et al. (1992) \\
Roskild Fjord, Denmark & 204 & Nienhuis (1992) \\
Bass Harbor Marsh, Massachusetts, USA & 225 & Kinney and Roman (1998) \\
Great Bay, New Hampshire, USA & 252 & Short and Mathieson (1992) \\
Quashnet River, Massachusetts, USA & 350 & Valiela et al. (2000a) \\
Wadden Sea, Northern Europe & 500 & Nienhuis (1992) \\
Childs River, Massachusetts, USA & 601 & Valiela et al. (2000a) \\
\hline
\end{tabular}

$\mathrm{kg} \mathrm{N} \cdot \mathrm{ha}^{-1} \cdot \mathrm{yr}^{-1}$ (Valiela et al. 2001). It may be that within large bays such as Barnegat Bay, there is much spatial variation in the degree of eutrophication. This is evident in Barnegat Bay by the presence of remnant seagrass meadows (an indicator of low $\mathrm{N}$ regimes [Valiela and Cole 2002]) and by the presence of significant macroalgal blooms (evidence of high $\mathrm{N}$ regimes [Valiela et al. 1997b]).

Watershed-scale management of nitrogen loads to Barnegat Bay.-Use of the NLM in NLOAD made it possible to determine the sources of nitrogen that constitute the total nitrogen load (Table 5). Estimates based on the NLOAD tool determined that the total load to Barnegat Bay was $3.9 \times 10^{5} \mathrm{~kg} \mathrm{~N} / \mathrm{yr}$ (Table 5). Of that total load, $71 \%$ of the $\mathrm{N}$ was derived from atmospheric deposition on the watershed (Table 5). The remaining $29 \%$ resulted from the application of fertilizers within the watershed. This total does not include the additional $3.0 \times 10^{5} \mathrm{~kg} \mathrm{~N} / \mathrm{yr}$ that results from direct atmospheric deposition onto the surface of the estuary. If, instead of being sewered, Barnegat Bay had only conventional septic systems, as is typical of many other estuaries in the northeast United States and elsewhere, the total $\mathrm{N}$ load to the bay would be more than double current loads (from $3.9 \times 10^{5} \mathrm{~kg} \mathrm{~N} / \mathrm{yr}$ to $8.9 \times 10^{5} \mathrm{~kg}$ $\mathrm{N} / \mathrm{yr}$ ).

Since wastewater is not a dominant source of $\mathrm{N}$ to Barnegat Bay, managers can focus instead on managing nitrogen derived from atmospheric deposition and from fertilizer use. Unfortunately, management of atmospheric deposition poses some challenges, as airsheds tend to be much larger than watersheds (Dennis 1995), and thus regulation requires broader, regional control. There are, however, some indirect methods by which stakeholders can manage nitrogen from atmospheric sources. One of the most effective strategies for managing nitrogen from atmospheric sources is the preservation of naturally vegetated land, including forests and wetlands. Previous simulations with NLOAD indicate that a 1-ha parcel covered entirely by forest contributes $\sim 1.4 \mathrm{~kg} \mathrm{~N} / \mathrm{yr}$, but if that forested land were to be converted to agricultural land the load would increase by an order of magnitude (Bowen and Valiela 2004). This increase makes clear the importance of green space preservation for managing nitrogen from atmospheric deposition.

The NLOAD tool can also be used to assess the effectiveness of management strategies to reduce fertilizer nitrogen, the other major source of nitrogen entering coastal waters. We first used NLOAD to calculate the decrease in $\mathrm{N}$ that would occur if the use of agricultural fertilizers was reduced from the current rate of $136 \mathrm{~kg} \mathrm{~N} \cdot \mathrm{ha}^{-1} \cdot \mathrm{yr}^{-1}$ (Fig. 4). Presently, agricultural fertilizers contribute just over $115 \times 10^{3} \mathrm{~kg} \mathrm{~N} / \mathrm{yr}$ to the nitrogen load of Barnegat Bay (Table 5). If the dose of fertilizers applied to agricultural land were decreased, it would result in a significant decrease in the nitrogen load to Barnegat Bay (Fig. 4). For example, if farmers scaled back use of fertilizers to $50 \mathrm{~kg} \mathrm{~N} \cdot \mathrm{ha}^{-1} \cdot \mathrm{yr}^{-1}$, simulations run with NLOAD indicate that there would be a reduction of $\sim 7 \%$ in overall loading to Barnegat Bay (Fig. 4a). Similarly, if fewer homes used fertilizers on their lawns and gardens, the $\mathrm{N}$ load to receiving waters would decrease. For instance, if the number of families that use lawn fertilizer decreased from $34 \%$ to $10 \%$, there would be nearly a $12 \%$ decrease in $\mathrm{N}$ load to the bay (Fig. 4b). Combining these two specific management options would reduce loads by nearly $20 \%$.

These fertilizer simulations are just an example of the many simulations that can be run with NLOAD. Other possible simulations include improving septic system performance, adding waste treatment facilities, diverting

TABle 4. Comparison of the trophic status of Barnegat Bay relative to the trophic classification of Nixon (1995).

\begin{tabular}{lc}
\hline \hline $\begin{array}{c}\text { Trophic status } \\
\text { (Nixon 1995) }\end{array}$ & $\begin{array}{c}\text { Organic } \mathrm{C} \text { supply } \\
\left(\mathrm{g} \mathrm{C} \cdot \mathrm{m}^{-2} \cdot \mathrm{yr}^{-1}\right)\end{array}$ \\
\hline Oligotrophic & $<100$ \\
Mesotrophic & $100-300$ \\
Eutrophic & $300-500$ \\
Hypereutrophic & $>500$ \\
\hline
\end{tabular}

Note: Seitzinger et al. (2001) reported an organic C supply value of $490 \mathrm{~g} \mathrm{C} \cdot \mathrm{m}^{-2} \cdot \mathrm{yr}^{-1}$ for Barnegat Bay. 
TABLE 5. Modeled estimates of the total nitrogen load and the loads contributed by fertilizer addition to and atmospheric deposition on the subwatersheds of Barnegat Bay, New Jersey, USA.

\begin{tabular}{|c|c|c|c|c|c|c|}
\hline \multirow[b]{2}{*}{ Subwatershed } & \multirow{2}{*}{$\frac{\text { Total load }}{\mathrm{kg} \mathrm{N} / \mathrm{yr}}$} & \multicolumn{2}{|c|}{ Fertilizer load } & \multicolumn{2}{|c|}{ Atmospheric load } & \multirow{2}{*}{$\frac{\text { Wastewater load } \dagger}{\mathrm{kg} \mathrm{N} / \mathrm{yr}}$} \\
\hline & & $\mathrm{kg} \mathrm{N} / \mathrm{yr}$ & $\%$ of total & $\mathrm{kg} \mathrm{N} / \mathrm{yr}$ & $\%$ of total & \\
\hline Toms River-Kettle Creek & 172203 & 57698 & 34 & 114505 & 66 & 229841 \\
\hline Metedeconk River & 92302 & 39960 & 43 & 52342 & 57 & 162206 \\
\hline Ceder Creek-Forked River & 53661 & 7581 & 14 & 46080 & 86 & 39499 \\
\hline Mill Creek & 39267 & 5464 & 14 & 33803 & 86 & 29351 \\
\hline Oyster Creek & 20569 & 2610 & 13 & 17959 & 87 & 17181 \\
\hline Tuckerton Creek & 16635 & 2381 & 15 & 14254 & 85 & 16413 \\
\hline Entire watershed & $394637 \ddagger$ & 115694 & 29 & 278943 & 71 & 494491 \\
\hline
\end{tabular}

$\dagger$ Wastewater estimates are derived using the nitrogen loading model (NLM) and assuming that all houses in the watershed dispose of wastewater through on-site septic systems, instead of through offshore outfall.

\$ This total load estimate does not include the estimated potential contribution from wastewater.

runoff from impervious surfaces, altering zoning ordinances, preserving natural spaces such as forests and wetlands, harvesting macroalgae, increasing flushing time, and exterminating waterfowl (Bowen and Valiela 2004).

In actual practice, all of the management options that can be explored with NLOAD need to be further considered in the context of the socioeconomic and political interests of the community. For example, it may not be tenable to ask every resident in the entire watershed to stop the use of lawn fertilizers, but if there are smaller regions within the watershed where lawn fertilizers are particularly problematic, then more targeted management options may be more appropriate. That is one reason why we constructed NLOAD to work at different spatial scales.

Subwatershed-scale estimates of $N$ loads to Barnegat Bay.-The Toms River-Kettle Creek watershed is the largest subwatershed in Barnegat Bay, with $40 \%$ of the land area and $46 \%$ of the population (Table 1). As could be expected, the Toms River-Kettle Creek watershed contributes the largest amount of nitrogen to Barnegat Bay, accounting for $44 \%$ of all nitrogen entering the bay (Table 5). The Metedeconk watershed is the next largest contributor, accounting for $23 \%$ of the $\mathrm{N}$ entering the bay. Tuckerton Creek, the smallest of the Barnegat Bay watersheds contributes only $4 \%$ of the nitrogen load to the bay.

Subwatershed-scale management of $N$ loads to Barnegat Bay.-Simulations produced by NLOAD indicate that in all watersheds atmospheric deposition onto the watershed was the dominant source of nitrogen from the watershed, ranging in importance from $57 \%$ to $87 \%$ of the total nitrogen load (Table 5). In the Toms RiverKettle Creek watershed, $66 \%$ of the $\mathrm{N}$ was derived from atmospheric deposition on the watershed (29\% of the total load to Barnegat Bay) and 34\% was derived from fertilizers (15\% of the total load to Barnegat Bay). If human-derived wastewater in the Barnegat Bay subwatersheds was not disposed of through an offshore outfall, it would contribute dramatically to the nitrogen loads entering Barnegat Bay. In the two largest subwatersheds, Toms River and Metedeconk River, wastewater would have accounted for $>50 \%$ of the entire load from the subwatersheds (Table 5). In the smaller subwatersheds, wastewater would have accounted for nearly as much $\mathrm{N}$ as atmospheric sources (Table 5). This demonstrates the important role that managing wastewater has played in protecting Barnegat Bay and illustrates the magnitude of the role of wastewater in the eutrophication of other urbanized coastal embayments.

To illustrate how NLOAD can be used in a spatially explicit manner, we ran two additional simulations in which we used NLM to alter the fertilizer dose rate for both lawn fertilizers and agricultural fertilizers in the Toms River-Kettle Creek watershed (Fig. 5). These simulations indicate that decreasing the dose of fertiliz-

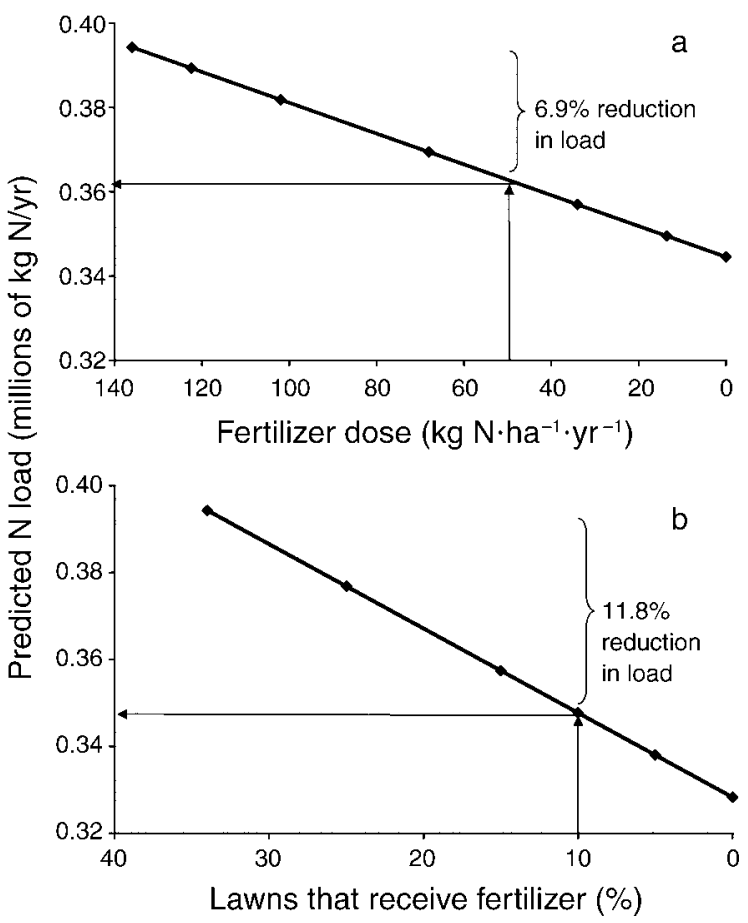

FIG. 4. Sample simulations to reduce the amount of fertilizer nitrogen entering Barnegat Bay by (a) decreasing the fertilizer dose on agricultural crops, or (b) by decreasing the percentage of lawns that receive fertilizer. 


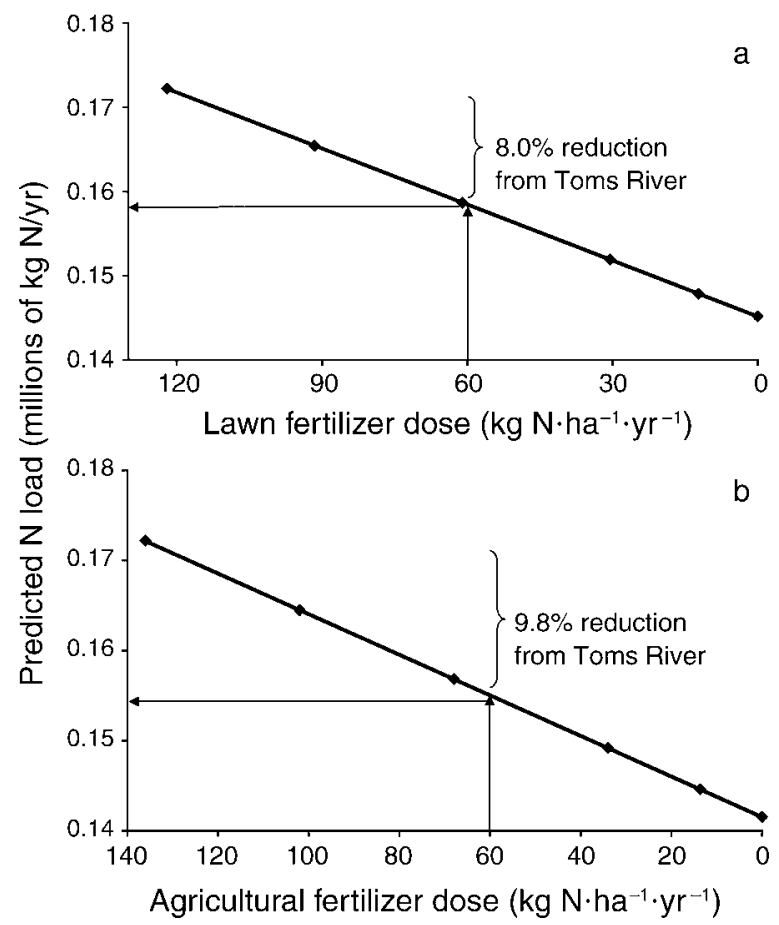

FIG. 5. Sample simulation to reduce nitrogen loading to Barnegat Bay by (a) reducing fertilizer use on lawns, and (b) agricultural land in the Toms River-Kettle Creek subwatershed of Barnegat Bay.

ers to lawns and agriculture, even to small subwatersheds within much larger systems, will result in a decrease in the nitrogen load entering receiving waters (Fig. 5). For example, if residents within the Toms River-Kettle Creek watershed reduced the amount of fertilizer that they added to their lawns from 136 to 60 $\mathrm{kg} \mathrm{N} \cdot \mathrm{ha}^{-1} \cdot \mathrm{yr}^{-1}$, it would result in an $8 \%$ reduction in the amount of $\mathrm{N}$ delivered from the Toms River-Kettle Creek watershed (Fig. 5a). Similarly, if farmers also reduced their fertilizer use to $60 \mathrm{~kg} \mathrm{~N} \cdot \mathrm{ha}^{-1} \cdot \mathrm{yr}^{-1}$, the result would be an additional reduction of almost $10 \%$ of the $\mathrm{N}$ from the Toms River-Kettle Creek watershed (Fig. 5b).

The results of these simulations are specific to the Barnegat Bay watershed and subwatersheds to which they were applied. Different land uses in different systems will lead to different results, and potentially different management recommendations. The simulations described here are by no means exhaustive of all the possible management scenarios. They are instead designed to illustrate how the NLOAD tool can be used to address management concerns at different spatial scales.

\section{Conclusions}

We have successfully created a user-friendly, interactive web site that is available to anyone interested in understanding $\mathrm{N}$ budgets to water bodies and in managing $\mathrm{N}$ loads. The NLOAD research and manage- ment tool allows users from various sectors and different levels of experience to perform several tasks, including estimate $\mathrm{N}$ loads from a watershed to a receiving water body, determine percentage contributions to total $\mathrm{N}$ loads from wastewater, fertilizer, and atmospheric deposition, and to calculate the mean annual concentration of $\mathrm{N}$ in an estuary. The NLOAD tool also assesses effectiveness of proposed management strategies to reduce nitrogen loads. Nitrogen load estimation and assessment of management strategies can also be performed at the subwatershed scale for systems such as Barnegat Bay. By providing a step-by-step guide to navigating the site, links to background information on $\mathrm{N}$ loading to coastal watersheds, and references to the original literature, the NLOAD site accommodates a wide range of users from researchers to concerned stakeholders.

\section{ACKNOWLEDGMENTS}

Support for the NLOAD tool came from the Cooperative Institute for Coastal and Estuarine Environmental Technologies (CICEET, CICEET-UNH grants \#02-610 and \#04-833). Additional funding was received from Environmental Defense. Programming work was performed by Andrew Ringler. Many coastal managers and planners provided us with valuable feedback during the development of NLOAD. We thank Richard Langan and Dwight Trueblood at CICEET; Christine Gault, Chris Weidman, Brendan Annett, and Anne Reynolds from the Waquoit Bay National Estuarine Research Reserve; John Brawley from Battelle Memorial Institute; Daniel Bacon from the Falmouth Planning Office; Todd Callaghan from Coastal Zone Management; Joe Costa from the Buzzards Bay Project; Robert Howarth and Roxanne Marino from Cornell University; Craig Swanson from Applied Science Associates; and Dave Enslinger from the National Oceanic and Atmospheric Administration's Coastal Services Center. We acknowledge technical support and advice from Amy Stout, Cathy Norton, David Remsen, and Barbara Inzina from the Marine Biological Laboratory. We also acknowledge two anonymous reviewers whose input improved this manuscript.

\section{Literature Cited}

Beaulac, M. N., and K. H. Reckow. 1982. Examination of landuse nutrient export relationships. Water Resources Research 18:1013-1024.

Bianchi, T. S., J. R. Pennock, and R. T. Twilley, editors. 1999. Biogeochemistry of Gulf of Mexico estuaries. Wiley, New York City, New York, USA.

Bologna, P., A. Wilbur, and K. Able. 2001. Reproduction, population structure and recruitment failure in bay scallop (Argopecten irradians) population from coastal New Jersey, USA. Journal of Shellfish Research 20:89-96.

Bowen, J. L., and I. Valiela. 2004. Nitrogen loads to estuaries: using loading models to assess the effectiveness of management options to restore estuarine water quality. Estuaries 27: 482-500.

Boynton, W. R., J. D. Hagy, L. Murray, C. Stokes, and W. M. Kemp. 1996. A comparative analysis of eutrophication patterns in a temperate coastal lagoon. Estuaries 19:408-421.

Bricker, S. B., C. G. Clement, D. E. Pirhala, S. P. Orland, and D. G. G. Farrow. 1999. National estuarine eutrophication assessment: effects of nutrient enrichment in the nation's estuaries. National Oceanic and Atmospheric Administration (NOAA), National Ocean Service, Special Projects Office, and the National Centers for Coastal Ocean Science, Silver Spring, Maryland, USA. 
Caraco, N. F., and J. J. Cole. 1999. Human impact on nitrate export: an analysis using major world rivers. Ambio 28:167170.

Cole, J. J., B. L. Peierls, N. F. Caraco, and M. L. Pace. 1993. Nitrogen loading of rivers as a human-driven process. Pages 138-154 in M. J. McDonnell and S. T. A. Pickett, editors. Humans as components of ecosystems: the ecology of subtle human effects and populated areas. Springer-Verlag, New York City, New York, USA.

Cole, M. L., I. Valiela, K. D. Kroeger, G. L. Tomasky, J. Cebrian, C. Eigand, R. A. McKinney, S. P. Grady, and M. H. Carvalho da Silva. 2004. Assessment of the $\delta^{15} \mathrm{~N}$ isotopic method to indicate anthropogenic eutrophication in aquatic systems. Journal of Environmental Quality 33:124132.

Costa, J. E., B. L. Howes, D. Janik, D. Aubrey, E. Gunn, and A. E. Giblin. 1999. Managing anthropogenic nitrogen inputs to coastal embayments: technical basis of a management strategy adopted for Buzzards Bay. Buzzards Bay Project Technical Report. Wareham, Massachusetts, USA.

Dennis, R. L. 1995. Using the regional acid deposition model to determine the nitrogen deposition airshed of the Chesapeake Bay watershed. Pages 393-413 in J. E. Baker, editor. Atmospheric deposition of contaminants to the Great Lakes and coastal waters. SETAC Press, Pensacola, Florida, USA.

Dettmann, E. 2001. Effects of water residence time on annual export and denitrification of nitrogen in estuaries: a model analysis. Estuaries 24:481-490.

Gaines, A. G. 1986. Lagoon pond study: an assessment of environmental issues and observations on the estuarine system. Final report for the town of Oak Bluffs. Woods Hole Oceanographic Institution, Woods Hole, Massachusetts, USA.

Goldberg, E. D. 1995. Emerging problems in the coastal zone for the twenty-first century. Marine Pollution Bulletin 31: $152-158$.

Group of Experts on the Scientific Aspects of Marine Pollution (GESAMP). 1990. State of the marine environment. Reports and Studies No. 39. GESAMP, United Nations Environment Programme, Nairobi, Kenya.

Howarth, R. W., et al. 1996. Regional nitrogen budgets and riverine $\mathrm{N}$ and $\mathrm{P}$ fluxes for the drainages to the North Atlantic Ocean: natural and human influences. Biogeochemistry $35: 75-139$.

Hunchak-Kariouk, K., and R. S. Nicholson. 2001. Watershed contributions of nutrients and other non-point source contaminants to the Barnegat Bay-Little Egg Harbor estuary. Journal of Coastal Research Special Issue 32:28-81.

Johnes, P. J. 1996. Evaluation and management of the impact of land use changes on the nitrogen and phosphorus load delivered to surface waters: the export coefficient modeling approach. Journal of Hydrology 183:323-349.

Kellogg, D. Q., L. Joubert, and A. Gold. 1996. Technical documentation, nutrient loading component of the MANAGE Geographic Information System-based risk assessment method. University of Rhode Island Cooperative Extension, Department of Natural Resources Science, Woodward Hall, Kingston, Rhode Island, USA.

Kennish, M. J. 2001. State of the estuary and watershed: an overview. Journal of Coastal Research Special Issue 32:3-12.

Kennish, M. J., S. B. Bricker, W. C. Dennison, P. M. Glibert, R. J. Livingston, K. A. Moore, R. T. Noble, H. W. Paerl, J. M. Ramstack, S. Seitzinger, D. A. Tomasko, and I. Valiela. 2007. Barnegat Bay-Little Egg Harbor Estuary: case study of a highly eutrophic coastal bay system. Ecological Applications 17:S3-S16.

Kinney, E. H., and C. T. Roman. 1998. Response of primary producers to nutrient enrichment in a shallow estuary. Marine Ecology Progress Series 163:89-98.
Lee, V., and S. Olsen. 1985. Eutrophication and management alternatives for the control of nutrient inputs to Rhode Island coastal lagoons. Estuaries 8:191-202.

McClelland, J. W., and I. Valiela. 1998. Linking nitrogen in estuarine producers to land-derived sources. Limnology and Oceanography 43:577-585.

McClelland, J. W., I. Valiela, and R. H. Michener. 1997. Nitrogen stable isotope signatures in estuarine food webs: a record of increasing urbanization in coastal watersheds. Limnology and Oceanography 42:930-937.

New Jersey Department of Environmental Protection (NJDEP). 2002. Shellfish stock assessment of Little Egg Harbor. Technical report, NJDEP, Trenton, New Jersey, USA.

Nienhuis, P. H. 1992. Eutrophication, water management, and the functioning of Dutch estuaries and coastal lagoons. Estuaries 15:538-548.

Nixon, S. W. 1995. Coastal marine eutrophication: a definition, social causes, and future concerns. Ophelia 41:199-219.

Nixon, S. W., C. A. Oviatt, J. Frithsen, and B. Sullivan. 1986. Nutrients and the productivity of estuarine and coastal marine ecosystems. Journal of the Limnology Society of South Africa 12:43-71.

O'Donohue, M. J. H., P. M. Glibert, and W. C. Dennison. 2000. Utilization of nitrogen and carbon by phytoplankton in Moreton Bay, Australia. Marine and Freshwater Research 51:703-712.

Olsen, P. S., and J. B. Mahoney. 2001. Phytoplankton in the Barnegat Bay-Little Egg Harbor estuarine system: species composition and picoplankton bloom development. Journal of Coastal Research Special Issue 32:115-143.

Omernik, J. M. 1976. The influence of land use on stream nutrient levels. EPA Report 600/3-76-014.

Paerl, H. W., and D. R. Whitall. 1999. Anthropogenicallyderived atmospheric nitrogen deposition, marine eutrophication, and harmful algal bloom expansion: Is there a link? Ambio 28:307-311.

Seitzinger, S. P., R. M. Styles, and I. E. Pilling. 2001. Benthic microalgal and phytoplankton production in Barnegat Bay, New Jersey (USA): microcosm experiments and data synthesis. Journal of Coastal Research Special Issue 32: $144-162$.

Sfriso, A., B. Pavoni, A. Marcomini, and A. A. Orio. 1992. Macroalgae, nutrient cycles, and pollutants in the lagoon of Venice. Estuaries 25:517-528.

Short, F. T., and A. C. Mathieson. 1992. Primary producers. Pages 145-189 in F. T. Short, editor. The ecology of the Great Bay Estuary, New Hampshire and Maine: an estuarine profile and bibliography. NOAA Coastal Ocean Program, New Hampshire Sea Grant College Program, Durham, New Hampshire, USA.

Soranno, P. A., S. L. Hubler, S. R. Carpenter, and R. C. Lathrop. 1996. Phosphorus loads to surface waters: a simple model to account for spatial pattern of land use. Ecological Applications 6:865-878.

Valiela, I., and J. L. Bowen. 2002. Nitrogen sources to watersheds and estuaries: role of land cover mosaics and losses within watersheds. Environmental Pollution 18:239248.

Valiela, I., J. L. Bowen, and K. D. Kroeger. 2002. Assessment of models for estimation of land-derived nitrogen loads to shallow estuaries. Applied Geochemistry 17:935-953.

Valiela, I., and M. L. Cole. 2002. Comparative evidence that salt marshes and mangroves protect seagrass meadows from land-derived nitrogen loads. Ecosystems 5:92-102.

Valiela, I., M. L. Cole, J. W. McClelland, J. Hauxwell, J. Cebrian, and S. Joye. 2001. Salt marshes as part of coastal landscapes. Pages 23-38 in M. P. Weinstien and D. A. Kreger, editors. Concepts and controversies in tidal marsh ecology. Kluwer, Dordrecht, The Netherlands. 
Valiela, I., G. Collins, J. Kremer, K. Lajtha, M. Geist, B. Seely, J. Brawley, and C.-H. Sham. 1997a. Nitrogen loading from coastal watersheds to receiving estuaries: new method and application. Ecological Applications 7:358-380.

Valiela, I., K. Foreman, M. LaMontagne, D. Hersh, J. Costa, P. Peckol, B. DeMeo-Anderson, C.-H. Sham, J. Brawley, and K. Lajtha. 1992. Couplings of watersheds and coastal waters: sources and nutrient enrichment in Waquoit Bay, MA. Estuaries 15:443-457.

Valiela, I., M. Geist, J. McClelland, and G. Tomasky. $2000 a$. Nitrogen loading from watersheds to estuaries: verification of the Waquoit Bay nitrogen loading model. Biogeochemistry 49:277-293.

Valiela, I., S. Mazzilli, J. L. Bowen, K. D. Kroeger, M. L. Cole, G. Tomasky, and T. Isaji. 2004. ELM, an estuarine nitrogen loading model: formulation and verification of predicted concentrations of dissolved inorganic nitrogen. Water Air Soil Pollution 157:365-391.

Valiela, I., J. McClelland, J. Hauxwell, P. J. Behr, D. Hersh, and K. Foreman. 1997b. Macroalgal blooms in shallow estuaries: controls and ecophysiological and ecosystem consequences. Limnology and Oceanography 42:1105-1118.

Valiela, I., G. Tomasky, J. Hauxwell, M. L. Cole, J. Cebrian, and K. D. Kroeger. 2000b. Operationalizing sustainability: management and risk assessment of land-derived nitrogen loads to shallow estuaries. Ecological Applications 10:1006 1023.

Vollenweider, R. A. 1976. Advances in defining critical loading levels for phosphorus in lake eutrophication. Memoire dell'Isituto Italiano de Idrobiologia 33:53-83.

\section{APPENDIX A}

A list of models used to estimate nitrogen loads and concentrations within the NLOAD web-based tool (Ecological Archives A017-062-A1).

\section{APPENDIX B}

Screen captures of the NLOAD web-based tool (Ecological Archives A017-062-A2). 